\title{
James B. Morris Sr. and the lowa Bystander
}

Henry G. La Brie III

Professor La Brie's article is part of a larger study of the black press in America. The original research was done with the support of the Ford Foundation. La Brie interviewed seventy-three elderly black journalists in forty-one cities in the United States. This article was written under the sponsorship of the National Endowment for the Humanities at Harvard University's Charles Warren Center, where La Brie was a post-doctoral fellow in 1972-1973. -Ed.

WHEN JAMES B. MORRIS SR. SOLD the lowa Bystander in 1971, it marked the end of a remarkable publishing career which spanned forty-nine years. The Bystander, now edited in Des Moines by Raymond Ray and re-named the New lowa Bystander, was founded in 1894 and remains today as one of the five oldest commercial black newspapers in publication. 'Although its name suggests non-involvement and inaction, the Bystander under Morris' direction was a crusader for equal opportunity and sought to prevent indifference in the area of race relations.

The Bystander is an exception to the rules which have governed the growth and progress of the black press. The paper is almost eighty years old. The life span of the average black newspaper has been estimated at nine years, ${ }^{2}$ due mainly to a lack of advertising support and the inability to find and keep trained personnel.

in March 1973 the black press celebrated its 146th anniversary,

\footnotetext{
${ }^{1}$ The other papers in this group include the Philadelphia Tribune (1885), Houston Informer (1892), Baltimore Afro-American (1892) and the Indianapolis Recorder (1895). There are also several religious newspapers of pre-1900 vintage including the Nashville Christian Recorder (1846), Louisville American Baptist (1880) and the Charlotte (N.C.) Star of Zion (1876).

${ }^{2}$ Armistead S. Pride, "The Negro Newspaper: Voice of a Minority," Midwest Journal (Winter 1950-51), p. 91.
} 
and 208 newspapers boasted a total weekly circulation of over 4.1 million. ${ }^{3}$ To best appreciate the accomplishments of Mr. Morris, it is valuable to know something of the history of black newspapers. Placed in this perspective, he emerges as one of the most dedicated black journalists in America.

The black press dates back to 1827 when John Russwurm and Samuel Cornish started Freedom's Journal in New York City. ${ }^{4}$ The paper was conceived after the editor of the New York Sun refused to publish a letter to the editor written by Russwurm and Cornish. The two men had written the Sun in response to a racist article it had printed.

What may be referred to as the first growth period of the black press, 1827-1865, was highlighted by the birth of about forty black newspapers. ${ }^{5}$ Only one, L'Union a half French, half English newspaper in New Orleans, was started in the South. Perhaps the most noteworthy paper of the period was Frederick Douglass' The North Star (1843), which tended to be of more literary than informational value.

During the period $1866-1900$, a great majority of over 1,200 black newspapers were initiated in the South. ${ }^{6}$ Nearly ninety per cent of the blacks in America during this time lived in the South. ${ }^{7}$ Between 1901 and 1973 a majority of the newly established 1,400 black papers were started in the South. ${ }^{8}$ Of the more than 2,600 newspapers founded since 1866 , seventy per cent commenced publication in the South. ${ }^{9}$

The black press, too, had its personalities. Marcus Garvey, a reformer and printer who gained great notoriety through his Pan-Africa movement, started three newspapers during the early 1900s. His Negro World (1917) was filled with news about the Universal Negro Improvement Association, which Garvey founded in 1911 in support of his "back to Africa" campaign.

\footnotetext{
${ }^{3}$ Henry G. La Brie, The Black Press in America: A Guide (Kennebunkport, Me.: Mercer House Press, 1973).

${ }^{4}$ Within two years, Russwurm left the paper and Cornish took full control. The name Freedom's Journal was changed to Rights For All but the paper ceased publication in 1830 .

${ }^{5}$ Pride, op. cit., pp. 91-92.

${ }^{6}$ lbid.

${ }^{7}$ Peter M. Bergman (ed.), The Chronological History of the Negro in America (New York: Harper and Row, 1969), 327.

${ }^{8}$ Pride, loc. cit.

${ }^{9}$ Ibid.
} 
Plummer Young (Norfolk Journal and Guide 1909), Roscoe Dunjee (Oklahoma City Black Dispatch 1901), Robert Abbott (Chicago Defender 1905), E. Washington Rhodes (Philadelphia Tribune 1895), Chester A. Franklin (Kansas City Call 1919), T. Thomas Fortune (New York Age 1902), Robert Lee Vann (Pittsburg Courier 1910), and Dr. John Murphy Sr. (Baltimore Afro-American 1892) all started black newspapers on a solid foundation. With the exception of the New York Age, all of the above are still publishing.

Of nearly 2,700 black newspapers begun since 1827, 208 are still publishing. Indeed, black newspapers have failed the great challenge: remaining alive. They have traditionally been unable to retain competent personnel. In most instances, the editors have been forced to train new staff members to a level of proficiency only to lose them to white establishment newspapers. Small staffs and a high rate of turnover have resulted in spotty news reporting, overuse of insignificant news and cluttered news columns. Antiquated methods of circulation failed to meet a need for increasing distribution. In the past, due mostly to their national subscription lists, black newspapers have been mail circulated.

Competition with establishment mass media has grown to new heights since 1955 at which point expanded coverage of black affairs in America began. In the past, black families seeking news of their community and of black people generally, subscribed to black newspapers. And, because advertising income was second to circulation (the reverse, of course, has almost always been true for the white establishment press), black journals had some security because they offered a product unavailable elsewhere. Now that white journals have broken the news monopoly formerly held by black newspapers the latter have been forced to seek new income to remain alive.

Fortunately, advertisers have realized that the black American is an important consumer to be reckoned with, and black newspapers are beginning to show profits as the income channels reverse; advertising revenue is surpassing circulation revenue. The increasing income and a cognizance of shifting priorities in the black ghetto have stabilized this black medium. Editors can now compete for journalistic talent, both black and white. Stronger staffs will allow the black newspaper to compete with its cross-town rival. 
The black press is attempting to highlight the more positive forces within the community; crusading and crime reporting have become less important reportorial tasks. Education, housing, welfare, employment, and cultural identity have taken on new meaning. While black newspapers may have erred in the past by aiming their news at the poor, an attempt is now being made to appeal to blacks at all economic levels. And, their appeal trancends an economic guise; black newspapers are seeking to reach the militant and the silent majority, as well as the moderate.

It seems as though black newspapers are beginning to recognize that it will be to their own best interests to become a supplement to, rather than a substitute for, the black person's news diet. Publishers and editors are seeking to continue to be a major factor which determines and guides black thought in America. They are doing so the best way they know how: supplying a black perspective to events, people and ideas in today's news.

$$
\text { \# \# }
$$

James B. Morris Sr. was born in Atlanta, Georgia on November 15,1890 . He confesses that he had printer's ink in his blood at an early age. "At the age of twelve I began working in a little print shop in Covington, a suburb of Atlanta," 10

After completing his grammar school in Atlanta, Morris moved to Baltimore where he attended high school and matriculated at Hampton Institute. "I worked the first year at Hampton. It was the custom then to work your first year to make enough money to attend school the second," Morris reported. At Hampton, he took a printing course and became so interested in the field that he declared it his major. In 1911, he graduated from the printing department and immediately entered the academic program. During the summers, Morris and several of his classmates worked at Asbury Park, New Jersey. His roommate's father was a lawyer in Portsmouth, Virginia and it was mainly this influence that convinced Morris to attend Howard University Law School after graduating from Hampton in 1912.

${ }^{10}$ This quote and all quotations and information by and about James $B$. Morris Sr. and the lowa Bystander were gathered during a personal interview with Morris, April 9-10, 1971, Des Moines, lowa. The tape of this interview is in the author's possession. 
Again, Morris sought summer employment to provide income with which he could pay tuition, room and board. He secured a job on the Hudson River Day Line sightseeing boat that traveled up and down the Hudson River. He kept this job every summer throughout the Howard years. Of all his extra-curricular activities, Morris most enjoyed the debating society. One of the society's guest speakers, Senator William E. Borah (R-Idaho), initially gave Morris the idea that the West was filled with opportunity and in need of good lawyers. Borah suggested that several of the young black law students consider setting up practice in the West.

Morris graduated from Howard in June 1915 and got a job as dining car waiter with the Great Northern Railroad. Based out of Great Falls, Morris spent one year in Montana before coming to Des Moines, where another Howard graduate had established a prominent law practice. He passed the lowa state bar examination on June 5, 1917, eight days before he entered the United States Army. Stationed at Fort Des Moines, he entered and completed the officer training program.

On April 16, 1918 Morris married Georgine Crowe, a dress designer in Des Moines. One month later he left for France and World War I, a lieutenant in the lowa 366th Infantry. After suffering a leg wound, he was sent to Camp Upton, New York to recover in May, 1919. He was later transferred to Fort Des Moines and eventually discharged on July 7, 1919.

A close friend of Morris' was running for County Treasurer at the time and promised Morris that if he could deliver the black vote, one of his first actions as County Treasurer would be to appoint a Negro deputy. His friend won and kept his promise. In December, 1920 James B. Morris Sr. was appointed Deputy County Treasurer. He held the position until January 1924.

Meanwhile, Morris ardently attempted to establish his law practice but, as he confesses, "There really wasn't much business for a Negro lawyer in those days." In late November 1922 he purchased the lowa Bystander from Lawrence Jones. And, after leaving his political job, he became more active in his law practice. He has filled this two-fold role ever since: lawyer and journalist.

In May, 1974 Morris and his wife will observe their 56 th wedding anniversary. They have two children, a son who shares the law practice with his father, and a daughter who is currently teaching at the University of Colorado medical school. 
In addition to practicing law for over fifty years, James $B$. Morris Sr. has a number of other achievements to his credit. In 1920-21, he served as state president of the lowa chapter of the National Association for the Advancement of Colored People. Mrs. Morris has also served as president and both are still active in NAACP affairs.

Morris, along with George Woodson, S. Joe Brown, Charles Howard and Mrs. Gertrude Rush, helped found the National Bar Association in Des Moines in 1931. All five re-grouped what was left of the older Negro Bar Association in an effort to provide a professional organization for Negro lawyers. At the time, the American Bar Association did not admit Negroes into its ranks. The NBA is still very active and Morris is the sole surviving founder.

In 1955-56 Morris was a member of lowa's advisory committee to the National Civil Rights Commission. And, in 1970, the city of Des Moines appointed Morris to its Human Rights Commission.

$$
\text { \# \# }
$$

The Bystander was organized in 1894 by I. E. Williamson, Billy Colson, and Jack Logan. All three men had other employment and Morris noted that this is a characteristic of Negro. editors. Williamson and his wife catered parties for the wealthy families of Des Moines; Colson was a butler; and Logan was a messenger in the state capitol. The fact that so many black newspapers have been extra-curricular activities or secondary employment for their owners, might also be considered as a contributing factor in the short life trait which has haunted so many black newspapers.

Morris believes two reasons directly explain why the Bystander was founded. First, the daily white press offered little, if any, employment for interested black journalists. A Negro interested in journalism either started his own newspaper or found other outlets for his talents, if possible. Second, daily white newspapers never carried Negro social news. Since there was a need to circulate this kind of information within the community, a specific medium was developed to meet the need.

During its early years of operation the Bystander sold for $\$ 1.50$ per year. In 1896 Charles S. Ruff, editor, Thaddeus S. Ruff, associate editor, and Joseph $\mathrm{H}$. Shepard, manager, resigned and J. L. Thompson bought the paper from its original owners. Although Shepard was later hired by Thompson, all three had quit because, 
according to an editorial, "We have labored under adverse conditions, from within and without." Thompson was a clever editor. Each summer he traveled around lowa soliciting subscriptions to maintain his newspaper. Circulation at the time was about 2,000. He never seemed satisfied with the paper's appearance and frequently changed the format. In April, 1900, the Bystander shifted to a six-column, eight-page format. The new editor was quick to make use of a network of news columnists who weekly sent reports to him detailing the latest Negro news in their communities. Thompson began running "Race Echoes" in 1900, a weekly column which reported black news on a nation-wide basis.

On March 21, 1902 the Bystander again changed appearance. This time it returned to its original format, a seven-column, four-page folio. An editorial in the newspaper explained that the Bystander had been enlarged on condition that advertising, subscriptions, and sufficient news of a general nature increased. But, since these had not occurred, the paper was returning to its original format. The editorial issued a plea for debtors to pay back their overdue subscriptions.

Most of the advertising in the Bystander during these formative years featured hair straighteners and skin bleachers. The cost of advertising was twenty cents per inch. In December, 1911 another column, "Afro-American Cullings" was initiated. The weekly feature was a synthesis of editorials appearing in other black newspapers in the United States. Poetry appeared in 1911, and the Bystander assumed a literary tone. Thompson also set about to sharpen up the paper through more frequent use of headlines, particularly atop each correspondent's column. Advertising rates increased to twenty-five cents an inch in 1914, thirty-five cents in 1918 , and eventually to forty cents in 1919. Shepard's name was removed from the masthead in June, 1913 and it is assumed that he left the Bystander at that time. Thompson retained control of the paper until 1920, when Lawrence Jones, a University of lowa graduate, bought the Bystander. Jones used the paper as a laboratory for students in his printing department but after two years of deficit operation, he sold the Bystander to James B. Morris, Sr. The transaction took place in November 1922.

Morris, who was at the time serving as Deputy County Treasurer, inherited a newspaper with a circulation of 3,000 . Since 1922, 
circulation has fluctuated up and down but it has never fallen below 2,000 and never exceeded 4,200.

Hiring competent people was the greatest challenge for Morris. He trained almost every staff member himself. He believes his second biggest challenge was maintaining circulation.

From 1894 to January 1969, the Bystander was produced by means of the letterpress method. It is now printed by means of the offset process. During its eighty-year lifetime, there was only one short period when the Bystander was not job-lotted to a local printer. The exception was in 1938-39 when Morris purchased a linotype machine and attempted to print the paper himself. "We only used that machine two or two and a half hours a week and that's far from enough to make a linotype machine profitable," related Morris.

Although Morris did not own the Bystander during the First World War, he recalled that the pages were filled with information about the officers training camp in Des Moines, where the first regiment of Negro candidates were preparing to become officers.

During the Second World War, the Negro began to gain more opportunities than he had ever had in the past. Bystander editorials supported this early emerging civil rights movement and stressed the hope for equal opportunities in all phases of life. Equal rights in the armed forces were of particular concern at this time.

Both war periods represented high rises in Negro employment. In the First World War, large numbers of blacks left the South to work in northern steel mills and other heavy industry. Yet, the jobs paid little and were still mediocre. During the Second World War, the Bystander strongly supported a national campaign to improve these conditions. Human Rights Commissions and Equal Opportunity programs began to appear across the country in the fifties, and the Bystander encouraged their contributions. Of course, the major event of the fifties was Brown vs. the Board of Education (1954); the Bystander positively advocated all parts of this landmark decision.

The sit-ins and marches of the late fifties upset Morris, but he became even more concerned during the militant sixties. As pleased as he is that the decade was a period of great change, he is deeply grieved because of the turmoil and confusion of priorities caused by the militant action of a few. He explained, "I have always supported 
an orderly process of change. The Constitution, while viewed by many as our greatest drawback, has actually upheld many rights of the Negro; rights that would have never existed had they not been written down. We have a lot to thank the Constitution for and I hope we can work through it and not against it."

The Great Depression of the 1930s was as hard on the Bystander as it was on everything and everyone else. In fact, it almost killed the newspaper. Morris recalled, "Harvey Ingham, editor of the Register (Des Moines), one of the paper's greatest editorial writers, and a real friend of the Negro people in our city, called me the day after the Bystander had missed its first (and only) issue. When 1 told him how bad things were, he urged me to continue printing and he suggested that I visit some of the wealthier businessmen in Des Moines to request financial assistance to maintain the newspaper. He told me he would begin the fund himself, with a $\$ 100$ donation. In a few weeks, I was able to solicit more than $\$ 700$ and we were able to pull the paper through the hard times (1929-30)."

Circulation during the Depression dropped back to 2,000. By 1940 it stood at 2,500 but it wasn't until the late fifties that it again started to rise. In 1960 the Bystander circulation was slightly over 2,700. In 1973 the New lowa Bystander was distributing over 3,200 copies each week, and presently is distributing 4,200 .

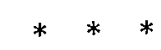

Notes on Contributors

Dave Etter majored in history at the University of lowa, earning a B.A. degree in 1953. Of his work he has said, "I am obsessed with the American Middle West and most of my poems are the result of that obsession." He now lives in Geneva, Illinois. 
Copyright of Annals of Iowa is the property of State of Iowa, by \& through the State Historical Society of Iowa and its content may not be copied or emailed to multiple sites or posted to a listserv without the copyright holder's express written permission. However, users may print, download, or email articles for individual use. 